\title{
Corruption - Why and How; a Moral-Economic Analysis
}

\author{
Rezwanul Kabir \\ School of Public Administration, China University of Geosciences, Wuhan, China
}

Email address:

1201790055@cug.edu.cn, rez_zimi@yahoo.com

\section{To cite this article:}

Rezwanul Kabir. Corruption - Why and How; a Moral-Economic Analysis. International Journal of Economy, Energy and Environment. Vol. 6, No. 2, 2021, pp. 18-28. doi: 10.11648/j.ijeee.20210602.11

Received: December 21, 2020; Accepted: December 30, 2020; Published: April 20, 2021

\begin{abstract}
Corruption emerged as one of main socio-political and economic problems of the countries which lead fortitude of its governments. No doubt, corruption has major implications for the distribution of income and wealth in the country, for its leading to specific patterns of expenditure and investment which leads to the illegal generation of wealth and the black money economy. As a consequence, in this paper we analyzed those significant causes of corruption on which insufficient attention has been given and ignored to the social dimension of emerging economic issues, despite the fact that social and economic issues are interlinked. Pertaining to this, we provided strong evidence of the existence of a causal link of corruption by presenting exploratory scholarship estimates using in-depth interviews of our sample households as instruments in the ground level, and by showing that our explanatory factors are actual predictors of corruption. In contrast to the previous literature, we found strong evidence in favor of the theory that institutional amelioration on moral-economic basis reduces corruption. Hence there is a growing recognition about making different and essential approach theoretically on the subject of elucidation of corruption with the intention of social institutions in moral-economic dimension.
\end{abstract}

Keywords: Moral-economic Dimension, Corruption, Underemployment and Inflation, Social Institutions, Goals and Objectives

\section{Introduction}

The question of the macroeconomic impact of corruption has received a great deal of attention during the last few decades. In their definitions of corruption, economists often place emphasis on practices related to public decisions and retain a description close to that adopted by the World Bank for which corruption can be understood as the abuse of public or private office for personal gain [6]. It means Corruption is the misuse of public power or entrusted power (by elected politician or appointed civil servant, heritage, marriage, election, schooling, appointment or whatever else) for personal gain. It hurts everyone who depends on the integrity of people in a position of authority [21].

A much more difficult, scientific definition for the concept 'corruption' was developed by Professor (emeritus) Dr. Petrus Van Duyne [15]: "Corruption is an improbity or decay in the decision-making process in which a decision-maker consents to deviate or demands deviation from the criterion which should rule his or her decision-making, in exchange for a reward or for the promise or expectation of a reward, while these motives influencing his or her decision-making cannot be part of the justification of the decision." [8]

Pertaining to these definitions, in simple words, it is to be said that a work which is not done in a given time and conditions, is a highly significant source of corruption. But this is not a single one that is highly significant source of corruption because it is confirm that corruption is not related to single phenomenon. And when we study of corruption with respect to the different countries, different regions, different cultures etc. we find a very controversial picture like different causes of corruption, different impacts of corruption and different discerning on corruption.

For developing countries particular in Bangladesh, circumstances are more complicated because there is amazing cultural diversity throughout the country. Therefore it is too difficult to reach an optimum point of solution of concern problem with single phenomenon. Hence it becomes necessary that study regarding solution of concerned critical problems should be in different perspectives, different objectives, through different tools etc. In this regards corruption is also a critical rising problem in Bangladesh that has different inputs and outputs which are associated with diversified socio- 
economic institutions of Bangladesh. And it is worldwide accepted theoretically and empirically that these institutions are highly significant factors of emerging economic issues of developing countries [1].

Challenging though these issues may be, we are now much better capable of understanding, and perhaps work towards redressing, the causes of these issues. Much of the progress on these issues has been made in economics, but the next step will require us to combine the insights and tools developed in economics with perspectives from other social sciences because it is concluded that the institutional values are deteriorating, being substituted by corruption which is getting the rank of a rising social value and is largely in practice amongst members of the general public, particularly in various economic aspects of social life. Nonetheless, people still believed that established social order is strong enough to combat this broken up dynamics, by generating a morality based milieu. If these factors lead to vigorous economic expansion, corruption is likely to decrease [19].

This paper discusses the meaning and concept of corruption with importance of institutions and its implication on ground problems like corruption and its measurement in the moral-economic analysis, in then followed by the same theme in the review of literature. The methodology is demonstrated in the third part of this paper. Findings and discussion are exposed in the fourth part. Finally, this paper will be closed with conclusion and suggestions.

\section{Review of Literature with Impact Evaluation Studies}

It is proved by theories and subsequent empirical evidences that corruption has a significant negative impact on sustainable development. In that case, the economic detriment of corruption on growth rates appears to be very large. A more corrupted society translates into lower rates of economic growth and thus reduces the ability of governments to alleviate poverty. In this respect, previous investigations have concentrated on various causes of corruption, quantitatively and qualitatively.

Pertaining to these the dominant mode of measurement since the mid-1990s has been perception-based, via crossnational analyses drawn from a range of surveys and expert assessments. Although the literature has provided important insights on the aggregate determinants of corruption, it has shortcomings. In particular, perception indices raise concerns about predispositions. Also, the comprehensive nature of the data tells us little about the relationship between corruption and individual agent. Conceptually macro-level determinants cannot satisfactorily explain of corruption for solution of this problem [17].

Because of, for measuring corruption by macro-level indices such as the Corruption Perception Index (CPI), the Bribe Payers Index (BPI), the Global Corruption Barometer, the Business Environment and Enterprise Performance Surveys (BEEPS) or other aggregate indicators such as the
Control of Corruption element in the World Bank Group's Worldwide Governance Indicators (WGI), have undoubtedly proved immensely important in raising awareness of the issue of corruption. However, it is now widely acknowledged that such measures are inherently prone to bias and serve as imperfect proxies for solution of corruption [11].

Indeed, measuring corruption has been described as 'more of an art form than a precisely defined empirical process' (UNDP 2008: 8). Moreover the lack of a convincingly agreed upon definition of what counts as corruption remains a serious obstacle to solute, as in practice specific indicators inevitably (even if implicitly) reflect particular definitions which can be used to support different findings [9].

Obviously there is a big controversy because of there is no proper and authenticated way for capturing of corruption particular in developing countries. And most significant cause of this situation is that there is found ethical, cultural, and institutional differences at cross country level. These factors make significant causes of corruption. The existing studies on corruption and its causes, demonstrated by many scholars might be the most comprehensive, but is not fully compatible and sufficient for solution of corruption in required perspective. The underlying theory and concept to solve problem of corruption is not based on actual rational behavior which is linked with ethical, cultural and institutional differences in developing countries. Thus measuring causes and their implications of corruption in moral-economic perspective would be more appropriate in developing countries particular in India because there is amazing cultural diversity throughout the country.

In doing so we analyses some books, reports, narratives and public documents for instance: a report on 'India Corruption Study-2008' by International Transparency [10], Rajeev K. Goal and Michael A. Nelson's paper 'Corruption and government size: A disaggregated analysis' [16], Georgios I. Zekos in Ethics versus corruption in globalization [7], Mohamed A. 'Arafa's 'Corruption And Bribery In Muslimic Law: Are Muslimic Ideals Being Met In Practice?' etc [12].

Pertaining to this literature, most studies are based on empirical perspective and some of them are on theoretical perspective. But at ground, there are only few studies which talk about problem of corruption in developing countries at individual and local level and tell us about causes of corruption to solute this problem at ground level. In this regards we tried to show third perspective or moral-economic perspective for solution of corruption in developing countries particularly in India. However it was difficult, but not impossible. We showed this using eight different data collection approaches: religion surveys, dowry surveys, inflation surveys, value less education surveys, underemployment surveys, prejudice and discrimination surveys, weak rules and regulations surveys and poor health surveys. Although each approach has a more general focus corruption - broadly defined - is often identified as a key issue e.g. some of them basic concept and definition are as following: 


\section{Concepts and Definitions}

The concepts and definitions of some imperative terms used in the survey and relevant to this paper are explained in the following points.

Household: A group of persons who usually lived together and took food from a common kitchen constituted a household (NSS Report No. 552: Employment and Unemployment Situation among Major Religious Groups in India) [13].

Employment: And in this group of persons, who was employed in public sector activities, were those activities which were sponsored by Government or Local Bodies, and which covered local area development works, is constituted (NSS Report No. 552: Employment and Unemployment Situation among Major Religious Groups in India) [13]. Besides this who was employed in private sector activities which were sponsored by private sector in similar manner are related to private sector employment, are constituted. It should be noted that in above mentioned activities, we are considered only those activities which are related to Grade IV or ' $\mathrm{D}$ ' group employment and their monthly income lies between Rs. 15-25 thousands (see CCS (CCA) Rules, 1965 and $6^{\text {th }}$ Pay Commission of India) $[4,20]$.

Religious group: For each household surveyed, the reported religion of the head of the household was well thought-out as the religion of all the members of the household irrespective of the actual religion followed by individual members (NSS Report No. 552: Employment and Unemployment Situation among Major Religious Groups in India) [13].

General educational level: A person was considered as educated in the terms of the general level of education that was collected in terms of highest level of education successfully completed. Diploma or certificate courses in general education, technical education or vocational education, which is correspondent to graduation level, was considered under the category 'graduate'. Similarly, diploma or certificate courses in general education, technical education or vocational education, which is equivalent to post-graduation level and above were considered under the category 'post-graduate and above' (NSS Report No. 552: Employment and Unemployment Situation among Major Religious Groups in India) [13].

\section{Methodology}

A study on "India Corruption Study-2008 with Special Focus on BPL Households" was designed and conducted by 'Centre for Media Studies' (CMS) issued by Transparency International India to measure the extent of petty corruption ${ }^{1}$. The study was based on perception, experience and estimation (PEE) model where the scope was not only limited to perceptions about corruption in general, but perception in specific context of a service and, more importantly, actual experience of paying bribe by BPL households in availing one or more of the eleven selected public services.

Depending on frequency of interaction, the eleven services were divided broadly into "basic services" (PDS, Hospital Service, School Education (up to $12^{\text {th }}$ ), Electricity Service and Water Supply Service) and "need based services" (Land Records/Registration, Housing Service, Forest, NREGS, Banking Service and Police Service (traffic and crime)). This model had brought out "the gap" between "Perception" and "Experience" in the context of citizen. The other aspect was "Estimation" of total money involved in corruption. On the ground of this model, they had ranked to Indian states and services in which corruption was found chronologically as following:

Table 1. According to level of Corruption Ranking of Services.

\begin{tabular}{llll}
\hline \multicolumn{2}{l}{ Services } & Rank & \multicolumn{2}{l}{ Services } & Rank \\
\hline 1 & Police & 7 & Electricity \\
2 & Land Records/Registration & 8 & Health \\
3 & Housing & 9 & PDS \\
4 & Water Supply & 10 & Banking \\
5 & NREGS & 11 & School Education (up to $12^{\text {th }}$ ) \\
6 & Forest & & \\
\hline
\end{tabular}

Source: India Corruption Study-2008

The grouping of States on corruption reflects relative position of States in the context of all eleven services. States under "alarming" group calls for serious introspection, reformation and even repositioning of certain services meant for BPL households. In Uttar Pradesh the level of corruption was "alarming" in all the eleven services studied. Since then circumstances has changed with respect to relative position of states but Uttar Pradesh remained same position even worse regarding to some studied services.

We know that corruption has two sides, each sustaining the other and reinventing itself. One is perception, the dimension which is relatively easy to talk about. The second is actual experience of corruption. Perception and experience are often two separate issues requiring take apart, but parallel efforts. Pertaining to this 'Corruption Study-2008' was based with special focus on BPL Households those were experienced by corruption of public sector. It was a one segment of perception and experience. But question is, had they been experienced by corruption of public sector really? If yes then why? Because service providers of public sector were also service receiver in other perspective and it means they were experienced from corruption too in other services. For that reason we analyzed causes of these results regarding eleven services in modified form, adopting the established concepts, definitions and procedures at ground level in Uttar Pradesh and we combined to these eleven public services in public as well as private services accepting that corruption is not joined with public sector only. 
Table 2. According to level of Corruption Ranking of States (arranged in alphabetical order).

\begin{tabular}{lllll}
\hline Levels of corruption & & \\
\hline States by size & Alarming & Very High & High & Moderate \\
\hline \multirow{2}{*}{ Big } & Assam, Bihar, Jammu \& Kashmir, & Karnataka, Rajasthan, & Chhattisgarh, Delhi, Gujarat, & Andhra Pradesh, Haryana, Himachal Pradesh, \\
Small/ Uts & Madhya Pradesh, Uttar Pradesh & Tamil Nadu & Jharkhand, Kerala, Orissa & Maharashtra, Punjab, Uttarakhand, West Bengal \\
\hline
\end{tabular}

Source: India Corruption Study-2008

Following the above approach and purpose of study we have used exploratory scholarship. We are collected information through reviewing available literature and/or qualitative approaches such as formal discussions, during the first half of October of the year 2014 by using in-depth interviews of household level sample survey, exit interviews at service delivery vents, discussions with the disturbed "service providers" etc. on various facets of corruption, implementing the established concepts, definitions and procedures at Uttar Pradesh in India. In which concepts, definitions and procedures are based primarily on the analysing of the reputed papers and reports which are mentioned in specified references in the end of this paper.

The critical issues in the context of various facets of corruption enquiries pertain to defining the corruption and measuring participation of these facets in different phenomenon of corruption. The activity participation of these facets is not only dynamic but also multidimensional; it varies over regions, religion, age, education, gender, industry and occupational categories. Thus people have different type of assertions on facets of corruption. Pertaining to this, in our survey, households are classified into various categories on the basis of assertions pursued by them.

At first they are classified by their districts, these were Sambhal, Moradabad, Aligarh, Bulandshahar and Hathras subject to the availability and then by location; urban, semiurban, and rural areas through Multi-Stage Random Sampling Technique. The urban and semi-urban frame survey blocks in the urban sector and rural frame survey villages in the rural sector are made by the list of 2001 census. Further the district level allocations for all rural, urban and semiurban areas were adjusted marginally to ensure that each stratum got a minimum allocation of 20 localities randomly.

Thus our sample included five urban areas -city Sambhal, city Moradabad, city Aligarh, city Bulandshahar and city Hathras in the composed districts, five semi-urban areas Gunnaur (Sambhal), Hasanpur (Moradabad), Khair (Aligarh), Khurja (Bulandshahar), Sadabad (Hathras) and five rural areas -Sirsi (Sambhal), Dilari (Moradabad), Jalalpur (Aligarh), Ahmad Nagar (Bulandshahar) and Mir Pur (Hathras). A census survey of the collected (300) household who were assigned as body of public and private employees at ' $\mathrm{D}$ ' group level, was conducted. In public and private employees, we considered those households who employed at their birth domicile and outside from it too because at rural level we found that there was very few households who were employed in their birth domicile. Out of 300 households 100 were employed in public sector while remaining were, private sector.

In this regards, the questionnaires focused on those factors which are responsible for increasing corruption at ground level and defined as factors which prevent or create obstacles to take advantages of services of educational institutions, health services, banking, manufacturing, managing, and overwhelming of administrative services by the underprivileged.

In doing so, we considered religion, dowry, inflation, value less education, underemployment, prejudice and discrimination, weak rules and regulations and poor health as explanatory factors of increasing corruption. These factors may include economic and non-economic both. The former may relate to poor/rich economic background of household. The non-financial factors may relate to educational, religious, community privileges, and cast of household. Information was also collected by observation, semi-structured interviews with important persons of the locality, and focus group discussions. Based on the data collected during the entire period of the survey, estimates pertaining to corruption and its causes in India along with various characteristics associated with them are presented in this paper.

\section{Findings and Discussions}

As noted earlier, the Sample Survey during the first half of October of the year 2014 carried out household survey of concerned service providers on the subject of corruption and its ground causes with solutions at Uttar Pradesh in India. In this survey included 300 households from all randomly collected areas of our composed districts.

Pertaining to these, It may be seen that table 3 shows, nearly 43 percent of them belonged to 'Others Religion' while 57 percent to Muslim. First group is called 'Others Households' group and second is 'Muslim Households'. In group 'Others Households' 37 percent are female and remaining 63 percent are male households, following subgroup 'Others Females' and 'Others Males' respectively, on the other hand, in group 'Muslim Households' 16 percent are female and remaining 84 percent are male households, following subgroup 'Muslim females' and 'Muslim males' respectively. Both group households are educated up to undergraduate to postgraduate level as mentioned above. 
Table 3. Frequency and percentage distributions of households by their religion and gender.

\begin{tabular}{llllll}
\hline S. No. & Others Households & \multicolumn{3}{l}{ Muslim Households } & Total \\
\hline 1 & 'Others males' & $80(35.71)$ & $144(64.28)$ & 'Muslim males' & $224(100.00)$ \\
2 & 'Others females' & $48(63.15)$ & $28(36.84)$ & 'Muslim females' & $76(100.00)$ \\
3 & Total & 128 & 172 & Total & 300 \\
\hline
\end{tabular}

Source: Self prepared questionnaire and field survey.

Note: - Number in table represent frequencies and number in parenthesis represent percentage proportion of total number of households of respective religion and gender.

Moreover, table 3 show also that household ratio of 'Muslim females' is less than up to 26.31 points from 'Others females'. Therefore there is a huge variation in answers which were received by both groups 'Others females' and 'Muslim females' in terms of experience of corruption. For that reason it to be seen in table 4 that at aggregate level group of 'Others females' gave less importance to inflation and weak rules and regulation for corruption than Muslim woman up to 10.52 points. On the other hand, this situation was opposite for 'Muslim males' as compare to 'others males'.

There are many causes of such types of responses, i.e. 'Muslim males' face entry barriers for getting services of educational institutions, health, banking, manufacturing, managing, and overwhelming of administrative due to religious discrimination which spring them depresses more than other community members etc.[3] and this is because value less education which is delivered to service providers at UG and PG level. To overcome this difficulty, they give bribe. Thus overall they gave more importance to prejudice and discrimination than inflation and weak rules and regulations for corruption comparatively to 'others males' up to 6.25 points. On the other hand, as compare to 'others females', 'Muslim females' assumed that inflation was more responsible for corruption because their economic and educational conditions were considerably serious as compare to 'others females' therefore rising in inflation would spoil their budget (NSS Report No. 552) [13]. And as a result they cannot be survived with increasing inflation by which corruption is increasing.

Table 4. Frequency and percentage distributions of household's responses by their districts and gender regarding inflation and weak rules and regulations as major causes of corruption.

\begin{tabular}{|c|c|c|c|c|c|c|c|c|c|}
\hline & \multirow{2}{*}{ Male } & \multicolumn{3}{|c|}{$\begin{array}{l}\text { Inflation and weak rules and regulations for } \\
\text { Corruption }\end{array}$} & \multirow{2}{*}{ Female } & \multicolumn{3}{|c|}{$\begin{array}{l}\text { Inflation and weak rules and regulations for } \\
\text { Corruption }\end{array}$} & \multirow{2}{*}{$\begin{array}{l}\text { Total Male and } \\
\text { Female (Urban, } \\
\text { Semi-urban and } \\
\text { Rural) }\end{array}$} \\
\hline & & $\begin{array}{l}\text { "Others } \\
\text { males" }\end{array}$ & $\begin{array}{l}\text { "Muslim } \\
\text { males" }\end{array}$ & $\begin{array}{l}\text { "Others males" + } \\
\text { "Muslim males" }\end{array}$ & & $\begin{array}{l}\text { "Others } \\
\text { females" }\end{array}$ & $\begin{array}{l}\text { "Muslim } \\
\text { females" }\end{array}$ & $\begin{array}{l}\text { "Others females" + } \\
\text { "Muslim females" }\end{array}$ & \\
\hline Sambhal & $46(76.66)$ & $20(43.47)$ & $14(30.43)$ & 34 (73.91) & $14(23.33)$ & 04 (28.57) & $08(57.14)$ & $12(85.71)$ & $60(100.00)$ \\
\hline Moradabad & $34(56.66)$ & $12(35.29)$ & $06(17.64)$ & $18(52.94)$ & $26(43.33)$ & $08(30.76)$ & $16(61.53)$ & $24(92.30)$ & $60(100.00)$ \\
\hline Aligarh & $50(83.33)$ & $10(20.00)$ & $14(28.00)$ & $24(48.00)$ & $10(16.66)$ & $02(20.00)$ & $04(40.00)$ & $06(60.00)$ & $60(100.00)$ \\
\hline Bulandshahar & $56(93.33)$ & $20(35.71)$ & $22(39.28)$ & $42(75.00)$ & $04(6.66)$ & $04(100.00)$ & $00(0.00)$ & $04(100.00)$ & $60(100.00)$ \\
\hline Hathras & $38(63.33)$ & $20(52.63)$ & $12(31.57)$ & $32(84.21)$ & $22(36.66)$ & $10(45.45)$ & $08(36.36)$ & $18(81.81)$ & $60(100.00)$ \\
\hline \multirow[t]{2}{*}{ Total } & $224(74.66)$ & $82(36.60)$ & $68(30.35)$ & $150(66.96)$ & $76(25.33)$ & $28(36.84)$ & $36(47.36)$ & $64(84.21)$ & $60(100.00)$ \\
\hline & & & & & & & & & 300 \\
\hline
\end{tabular}

Source: Self prepared questionnaire and field survey.

Note: - Number in table represent frequencies and number in parenthesis represent percentage proportion of respondents.

Such type of difference may be seen in table 5 also. Out of 74.66 percent households, 25.89 percent male households considered that degradation in social, religious and moral institutions was major cause of corruption than last one. Within this perception and experience, at aggregate echelon, 'Muslim males' convened this more than 'others males' that these types of factors were more significant than any other for corruption because last few decades it is noted that as these institutions are losing their importance, corruption is to be increased rapidly (Geetanee Napal, 2006) [2] and they are forced to take and give bribe by their seniors or officers.

Contrariwise situation was not different for postulation of 'Muslim females' because they preferred degradation impacts of social, religious and morals institutions on corruption up to 5.26 points more than 'Others females' on aggregate echelon. The most significant reason behind this is, most of them take primary education at Madrasas where they read about morally occupied social system (Report of the Standing Committee of the National Monitoring Committee for Minorities' Education, 2013) and that system does not allow any type of misuse of resources for individuals. Thus they measured any type of grant without work, in bribe and renounced it, on the other hand, 'others females' were less aware taking to this because they measured such type of grant as need of changing social system e.g. dowry system. 
Table 5. Frequency and percentage distributions of household's responses by their districts and gender regarding religion, value less education, dowry and prejudice and discrimination as a major causes of corruption.

\begin{tabular}{|c|c|c|c|c|c|c|c|c|c|}
\hline & \multirow{2}{*}{ Male } & \multicolumn{3}{|c|}{$\begin{array}{l}\text { Religion, Value Less Education, Dowry, } \\
\text { prejudice and discrimination for Corruption }\end{array}$} & \multirow{2}{*}{ Female } & \multicolumn{3}{|c|}{$\begin{array}{l}\text { Religion, Value Less Education, Dowry, } \\
\text { prejudice and discrimination for Corruption }\end{array}$} & \multirow{2}{*}{$\begin{array}{l}\text { Total Male and } \\
\text { Female (Urban, } \\
\text { Semi-urban } \\
\text { and Rural) }\end{array}$} \\
\hline & & $\begin{array}{l}\text { "Others } \\
\text { males" }\end{array}$ & $\begin{array}{l}\text { "Muslim } \\
\text { males" }\end{array}$ & $\begin{array}{l}\text { "Others males"+ } \\
\text { "Muslim males" }\end{array}$ & & $\begin{array}{l}\text { "Others } \\
\text { females" }\end{array}$ & $\begin{array}{l}\text { "Muslim } \\
\text { females" }\end{array}$ & $\begin{array}{l}\text { "Others females" + } \\
\text { "Muslim females" }\end{array}$ & \\
\hline Sambhal & $46(76.66)$ & $06(13.04)$ & 04 (8.69) & $10(21.73)$ & $14(23.33)$ & $00(0.00)$ & $00(0.00)$ & $00(0.00)$ & $60(100.00)$ \\
\hline Moradabad & $34(56.66)$ & 04 (11.76) & $08(23.52)$ & $12(35.29)$ & $26(43.33)$ & $00(0.00)$ & $02(7.69)$ & $02(7.69)$ & $60(100.00)$ \\
\hline Aligarh & $50(83.33)$ & $06(12.00)$ & $14(28.00)$ & $20(40.00)$ & $10(16.66)$ & $00(0.00)$ & $04(40.00)$ & $04(40.00)$ & $60(100.00)$ \\
\hline Bulandshahar & $56(93.33)$ & $06(10.71)$ & $04(7.14)$ & $10(17.85)$ & $04(6.66)$ & $00(0.00)$ & $00(0.00)$ & $00(0.00)$ & $60(100.00)$ \\
\hline \multirow[t]{2}{*}{ Total } & $224(74.66)$ & $24(10.71)$ & $34(15.17)$ & $58(25.89)$ & $76(25.33)$ & $02(2.63)$ & $06(7.89)$ & $08(10.52)$ & \\
\hline & & & & & & & & & 300 \\
\hline
\end{tabular}

Source: Self prepared questionnaire and field survey.

Note: - Number in table represent frequencies and number in parenthesis represent percentage proportion of respondents.

Table 6. Frequency and percentage distributions of household's responses by their districts and gender regarding Underemployment and Poor Health as major causes of corruption.

\begin{tabular}{|c|c|c|c|c|c|c|c|c|c|}
\hline & \multirow{2}{*}{ Male } & \multicolumn{3}{|c|}{$\begin{array}{l}\text { Underemployment and Poor Health for } \\
\text { Corruption }\end{array}$} & \multirow{2}{*}{ Female } & \multicolumn{3}{|c|}{$\begin{array}{l}\text { Underemployment and Poor Health for } \\
\text { Corruption }\end{array}$} & \multirow{2}{*}{$\begin{array}{l}\text { Total Male and } \\
\text { Female (Urban, } \\
\text { Semi-urban and } \\
\text { Rural) }\end{array}$} \\
\hline & & $\begin{array}{l}\text { "Others } \\
\text { males" }\end{array}$ & $\begin{array}{l}\text { "Muslim } \\
\text { males" }\end{array}$ & $\begin{array}{l}\text { "Others males" + } \\
\text { "Muslim males" }\end{array}$ & & $\begin{array}{l}\text { "Others } \\
\text { females" }\end{array}$ & $\begin{array}{l}\text { "Muslim } \\
\text { females" }\end{array}$ & $\begin{array}{l}\text { "Others females" }+ \\
\text { "Muslim females" }\end{array}$ & \\
\hline Sambhal & $46(76.66)$ & $02(4.34)$ & $00(0.00)$ & $02(4.34)$ & $14(23.33)$ & $02(14.28)$ & $00(0.00)$ & $02(14.28)$ & $60(100.00)$ \\
\hline Moradabad & $34(56.66)$ & 04 (11.76) & $00(0.00)$ & 04 (11.76) & $26(43.33)$ & $00(0.00)$ & $00(0.00)$ & $00(0.00)$ & $60(100.00)$ \\
\hline Aligarh & $50(83.33)$ & $02(4.00)$ & $04(8.00)$ & $06(12.00)$ & $10(16.66)$ & $00(0.00)$ & $00(0.00)$ & $00(0.00)$ & $60(100.00)$ \\
\hline Bulandshahar & $56(93.33)$ & $02(3.57)$ & $02(3.57)$ & $04(7.14)$ & $04(6.66)$ & $00(0.00)$ & $00(0.00)$ & $00(0.00)$ & $60(100.00)$ \\
\hline \multirow[t]{2}{*}{ Total } & $224(74.66)$ & $10(4.46)$ & $06(2.67)$ & $16(7.14)$ & $76(25.33)$ & $02(2.63)$ & $02(2.63)$ & $04(5.26)$ & \\
\hline & & & & & & & & & 300 \\
\hline
\end{tabular}

Source: Self prepared questionnaire and field survey.

Note: - Number in table represent frequencies and number in parenthesis represent percentage proportion of respondents.

For increasing dowry system, it is well known that households want to give and take as much as possible for their daughters and sons respectively. And such type of intention does not have any type of restriction on sources of earning money. And this type of problem is increased much more when we talk about public servants. Every public servant wants to see that his daughter is married off well and there is continuous pressure for having a minimum level of dowry. This may be one of the reasons why one comes across cases where even public servants who have had a clean life towards the end of their career become vulnerable to corruption. And most affected group of such type of problem is 'Others Households' relatively. ${ }^{2}$

In table 6 we measured different types of explanatory factors for corruption that are underemployment (i.e. those who are employed, but well below capacity in terms of ability or working time) and poor health of household. However, it is less significant as compare to former factors but not ignorable. Underemployment that is, always suggest to an employee to do about oneself by any means. In developing countries underemployment rate is high. The demand for steady sources of income is high, so, to safe and sound an earning position with stability and reasonable income opportunities, people are willing to make huge stash by any means (Ramli, 2006). Thus a high level of

2 Nature and Scope of Corruption in India, http://shodhganga.inflibnet.ac.in/bitstream/10603/8108/11/11_chapter\%202.pdf underemployment helps explaining the observed variations in corruption, particularly in developing countries [18].

Thus households think about it as a significant source of corruption. But more interesting point in this notion is that, 'others males' households give more importance to this factor as compare to 'Muslim males' household up to 1.79 points on aggregate while female of both groups on aggregate, have similar postulation on this factor. Because 'Muslim males' have less opportunities of employment than 'others males' thus they survive with present situation while 'others males' do not sort out that because they become more educated than 'Muslim males' (NSS Report No. 552) [13] and they face huge problem of underemployment. Therefore they engaged more in bribe then 'Muslim males' and measured that underemployment is a responsible cause of corruption.

On the other hand, we took a different type of explanatory factor that is, poor health which is a significant cause of increasing corruption because poor health decreases productivity and efficiency of work and increases expenditure. This situation creates demand for money for treatment and in developing countries health treatment is very costly in terms of earnings of households. And most affected group of this problem is 'others males' because they have not any concept of 'Halal' and 'Haram' in consumption and as a result they face huge critical health problems compare to 'Muslim males' as seen in table 6. Therefore they engaged more in bribe then 'Muslim males' and give more importance to poor health as a significant factor of increasing 
corruption with respect to increasing income by unfair means as compare to 'Muslim males.

On the ground of responses of households regarding to more and less significant causes of corruption, it may be measured by above description that first group of explanatory factors of corruption that were inflation and weak rules and regulations, were highly significant as compare to religion, value less education, dowry system, prejudice and discrimination because out of our 100\% samples, males and females respectively, $66.96 \%$ males and $84.21 \%$ females experienced it as primarily explanatory factors of corruption. On the other hand second group of explanatory factors was more significant than third group that was under employment and poor health because out of our $100 \%$ samples, males and females respectively, $25.89 \%$ and $10.52 \%$ males and females measured it as primarily explanatory factors of corruption. And out of our $100 \%$ samples, males and females only $7.14 \%$ males and $5.26 \%$ females measured factors of third group as primarily explanatory factors of corruption.

\section{Conclusion and Suggestions}

This study tried to understand role of the socio-economic factor in increase corruption in India. This paper is trying to address to answer the question "Why people are engage in corruption activity what factor motivate to do corruption". This paper uses the primary data to answer aforementioned problem. Thus it can be concluded that service providers of public as well as private sector are engaged with corruption. But this is not final experience because some socio-economic factors are responsible for these circumstances which are being increased problem of corruption. Respecting developing countries particularly India, it is essential to solve this problem at ground level as soon as possible. In this regards, many significant causes of increasing corruption are well known and some of those are; continuously increasing rate of inflation, weak rules and regulations, underemployment, social evils i.e. dowry system, value less education, poor health etc.

Moving forward requires first identifying where we want to be-the "last mile"-and then defining the strategy for getting there and the barriers to that strategy. Thus it is time to do work on these facilitators of corruption and barriers of sustainable development. In doing so, some result oriented decisions could be taken by policy makers and on the ground level, for implementation of these decisions, it is important at primary level that the people should come together without any distinction of race, caste, creed, language or sex. In this regards, many stepladder could be taken but as analyzed by us some most significant stepladder would be taken with priority, these are as following:

i. The solution to corruption is the elimination of its causes. Thus first step should be taken for inflation because in India, inflation rose sharply and this can be stopped and reduced by robust employment scenario and reduced underemployment etc. are some factors that could check inflation so that a balanced path of development could be framed which would be facilitators for reducing corruption.

ii. It is observed in India that the societal values have been diminishing over the past few decades which is one of those prominent causes that is significant for corruption. Therefore, it is necessary to develop the holistic citizenship education because it is important in any country since it promotes the knowledge, skills, habits, and values and these are basic tools of solution of corruption.

iii. Religion is the universal institution that's teachings are based on fairness and honesty. Its functions include moral wellbeing of its followers and social control in the society. It gives direction to behavior, discourages moral evils and encourages ethical values. Faithful attachment to religion ideally causes withdrawal from corruption. Unfortunately little attention is paid to determine the relationship between religion and corruption and use of religion in reducing corruption. Therefore, it is necessary to develop the religious ambience in this regards.

iv. Other causes of corruption are prejudice and discrimination by which one can choose non-optimum source of production. In that case, individuals face immense teething troubles in their workings especially in official workings, which procreate to corruption in different forms. In this situation, if prejudice and discrimination are learned, they can be "unlearned"; tolerance and acceptance and change the content of 'institutional learning techniques' that can be used to change people's attitudes about corruption.

v. Besides these, pass laws or establish judicial precedents in strong form that prohibit corruption directly.

vi. A silent cause of corruption is absence of concept of permitted and prohibited consumption or production too. In religious perspective, only Muslim be close to it convincingly i.e. prohibition of intoxicants, complete prohibition of infidelity, prostitution and other forms of sexual promiscuity etc. because such type of actions create not only health problems but others also which are elucidated by increasing demand of money irrespective of source of money that is a significant cause of corruption which can be solved through embargo of detrimental goods and activities as some of those described above.

On the ground of above, we provided some strong evidence of the existence of a causal link of corruption by presenting exploratory scholarship estimates using in-depth interviews of our sample households as instruments in the ground level, and by showing that our explanatory factors are actual predictors of corruption. In contrast to the previous literature, we found strong evidence in favor of the theory that institutional amelioration on moral-economic basis reduces corruption. For further analysis, given the difficulty of finding a convincing mechanism through theoretical analysis only, particularly for the developing countries, we 
have to leave a full investigation of advanced empirical causality with others facets of corruption for future work.

\section{Appendix}

Confidential

Corruption - Why and How; A Moral-Economic Analysis

Questionnaire for 'D' Group Employee of Public and Private Sector of Uttar Pradesh

Introduction

We are carrying out a study on some facets of corruption in India. For this purpose we are meeting a number of households of district of Uttar Pradesh in India, who belong to 'D' Group employment in public and private sector as well as reputed persons of different social groups in rural, urban and semi-urban areas to learn from them about their corruption related perceptions, experiences, opinion and their future plan for themselves in terms of solutions of corruption. This study is motivated by $11^{\text {th }}$ International NAPSIPAG Conference, Dhaka, Bangladesh on 'Asian Governance: Paradoxes of Development.

You will be glad to know that your name appeared in the list of households whom we would like to meet. We hope that you will kindly agree to cooperate in this study. On our part, we assure you that the information given by you will be used only in this study and will be kept strictly confidential; nowhere your name will be disclosed.

Please feel free and confident while answering the questions that given in this questionnaire. These are simple and relate to you. Therefore, you alone can answer. Just read the questions and also the list of answer given below the question. You will discover the appropriate answer you consider in the list. Please answer all questions. If you have any difficulty in filling the questionnaire, please consult the person who has given you this questionnaire.

We hope you will participate in this effort for solutions of corruption.

Many thanks.

Faizan Ali

Ministry of Minority Affairs Scholar,

School of Economics,

University of Hyderabad,

Hyderabad, India

Questionnaire

Identification of Households

This questionnaire contains 39 questions. Most of them have alternative answers. The respondent has to choose most appropriate answer and tick $[\sqrt{ }]$ at allied box, which is not applicable please leave that and follow instruction of allied question.

1. Name of the Household:

2. Gender (not ask but observe):

a) Male [ ]

b) Female [ ]

3. Domicile Area:
a) Urban [ ]
b) Semi-Urban [ ]
c) Rural [ ]

4. Name of Domicile Area:

5. Name of Domicile District:

6. Age of the Household (in complete years):

7. Where do you live at present?
a) His/her only domicile [ ]
b) Out of domicile [ ]

8. Give information:
a) Village/Town
b) Taluk/Block.
c) District

9. Which religious group you belong to:

10. Which social group you belong to:
a) Gen [ ] 

b) $\mathrm{OBC}[$ ]
c) $\mathrm{SC}[]$
d) ST [ ]
e) Others [ ]

11. Married status:
a) Single [ ]
b) Married [ ]
c) Widow [ ]
d) Widower [ ]
e) Divorced [ ]

12. Number of dependent individuals on Household:

13. How many dependent Individuals taking education:

14. How many of them are daughter (s)?

15. How many of them are son (s)?

16. How many of them taking education in domicile $(14+15)$ :

17. How many of them taking education at out of domicile $(14+15)$ :

18. Do you want to give dowry to your daughter (s)?
a) Yes [ ]
b) No [ ]
c) Can't say [ ]

19. Do you want to seize dowry for your son (s)?
a) Yes [ ]
b) No []
c) Can't say [ ]

20. Number of independent individuals of Household:

21. How many of them are doing work in public sector:

22. How many of them are doing work in private sector:

23. Attained Household's Education:
a) Up to Graduate [ ]
b) Post-Graduate and above [ ]

24. From where you did attain education?
a) Government institution [ ]
b) Private institution [ ]
c) Madrasa [ ]
d) All of above [ ]

25. Type of occupation:

a) Government salaried employee group ' $D$ ' [ ]

b) Private salaried employee (belong to Rs. 15-25 thousands monthly income [ ]

26. Department/section where the service was sought:

27. Are you satisfied with the service offered/gotten?
a) Yes [ ]
b) No [ ]
c) Can't say [ ]

28. Are you satisfied with the salary offered/gotten?
a) Yes [ ]
b) No [ ]
c) Can't say [ ] 
29. Are you feel excellent with your health and the services offered/gotten to you?
a) Yes [ ]
b) No [ ]
c) Can't say [ ]

30. What form (s) or practice (s) of corruption did encounter or experience in the course of seeking services given/gotten to you?
a) Abuse of office [ ]
b) Bribery demand [ ]
c) Favoritism [ ]
d) Tribalism/nepotism [ ]
e) None of above [ ]

31. At the place or office where service was being offered, did you give a bribe/unofficial payments or a favour in order to get services:
a) Yes [ ]
b) No [ ]
c) Don't want to tell [ ]

32. Compared to last year ago, how has the level of corruption changed in your institution?
a) Increased [ ]
b) Reduced [ ]
c) Remained the same [ ]
d) Don't know [ ]

33. How much pressure was exerted on you by public or private officers of your institution to engage in corruption?
a) A lot of pressure [ ]
b) A fair amount of pressure [ ]
c) A little pressure [ ]
d) No pressure at all [ ]

34. Who usually initiates a bribe?
a) A service provider indicates or asks for a payment [ ]
b) The person offers a payment on his/her own accord [ ]
c) It is known beforehand how to pay and how much to pay [ ]
d) Don't know [ ]

35. Has moral values based education a role for reducing corruption?
a) Yes [ ]
b) No [ ]
c) Can't say [ ]

36. Can we reduce to corruption by making strong rules and regulations?
a) Yes [ ]
b) No [ ]
c) Can't say [ ]

37. What would you do if you experience delays while waiting for the services in institution?
a) Won't worry, just wait, until it comes [ ]
b) Offer a bribe or a gift to the official [ ]
c) Lodge a complaint to the top management [ ]
d) Do nothing and give up [ ]

38. What are causes of increasing corruption at ground level in the following groups (give preference)?
a) Inflation and weak rules and regulations for Corruption [ ]
b) Declining faith in religion, Value Less Education, Dowry, prejudice and discrimination for Corruption [ ]
c) Underemployment and Poor Health for Corruption [ ] 


\section{References}

[1] Acemoglu, Daron, 2009, "Introduction to Modern Economic Growth", Princeton University Press.

[2] Asad Ullah and Mussawar Shah, 2013, "Does Pakistani Society Accept Corruption as a Changed Value with Reference to Religious Perspective?", International Journal of Basic \& Applied Sciences IJBAS-IJENS Vol: 13 No: 01.

[3] Amit A. Pandya, 2010, "Muslim Indians; Struggle for Inclusion”, 'The Henry L. Stimson Centre'.

[4] Classification, Control \& Appeal Rules, 1965, http://www.persmin.gov.in/DOPT/EmployeesCorner/Acts_Rul es/ccs(cca)/ccstotal1.htm.

[5] Dr. David A. Dilts, 2004, "Introduction to Microeconomics", Published by Indiana - Purdue University - Fort Wayne.

[6] Mohamed Dridi, 2014, "Corruption and Education: Empirical Evidence" International Journal of Economics and Financial Issues, Vol. 4, No. 3, 2014, pp. 476-493, ISSN: 2146-4138.

[7] Georgios I. Zekos, 2004, "Ethics versus corruption in globalization".

[8] http://www.corruptie.org/en/corruption/what-is-corruption/

[9] Hawken and Munck, 2009, "Measuring Corruption: A Critical Assessment and a Proposal".

[10] "India Corruption Study-2008 with Special Focus on BPL Households", 'Centre for Media Studies' (CMS) issued by Transparency International India.
[11] Kurtz and Shrank 2007, "Conceptualizing and Measuring Institutions: A View from Political Science".

[12] Mohamed A. 'Arafa's "Corruption and Bribery in Muslimic Law: Are Muslimic Ideals Being Met in Practice?"

[13] NSS Report No. 552: "Employment and Unemployment Situation among Major Religious Groups in India", NSS Report.

[14] Omer M. Othman Domoro and Syed Omar Syed Agil, 2012, "Factors Influencing Police Corruption in Libya - A Preliminary Study", International Journal of Economics and Management Sciences, Vol. 2, No. 2, 2012, pp. 25-35.

[15] Petrus C. van Duyne, "Will Caligula go transparent? Corruption in acts \& attitudes", Published in: Forum on Crime and Society, 2001, vol. 1, nr. 2, 73-98.

[16] Rajeev K. Goel and Michael A. Nelson, 1998 "Corruption and government size: A disaggregated analysis".

[17] Ritva Reinikka and Jakob Svensson, June 2003, "Survey Techniques to Measure and Explain Corruption", World Bank Policy Research Working Paper 3071.

[18] Saha, Shrabani and Gounder, Rukmani, 2009, "Corruption and Economic Development Nexus: Variation across Regions and Income Levels".

[19] Sayyid Musa Sadr, 2011, "Muslim, Humanity and Human Values" Journal: Vol. 11, N. 4, 2011, Publisher (s): Ahlul Bayt World Assembly.

[20] $6^{\text {th }}$ Pay Commission of India, http://finmin.nic.in/6cpc/6cpchighlights.pdf.

[21] Vito Tanzi, 1998, "Corruption Around the World: Causes, Consequences, Scope and Cures", IMF Working Paper. 